\title{
Dose Dependent Effects of Lithium Carbonate on Rat Thyroid Hormones, Parathormon and Calcium Levels with Thyroid Tissue
}

\section{Atilla Topçu}

Department of Pharmacology Faculty of Medicine, Recep Tayyip Erdoğan University, Rize, Turkey

Submitted: 05.02.2020 Accepted: 05.07.2020

Correspondence: Atilla Topçu, Recep Tayyip Erdoğan Üniversitesi Tıp Fakültesi Farmakoloji Anabilim Dalı, Rize, Turkey E-mail: atilla.topcu@erdogan.edu.tr

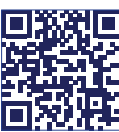

Keywords: Ca levels; lithium carbonate; parathormone; rat; thyroid hormones.

This work is licensed under a Creative Commons Attribution-NonCommercial 4.0 International License.

\begin{abstract}
Objective: The aim of this research was to investigate the effects of subacute use of lithium carbonate $\left(\mathrm{Li}_{2} \mathrm{CO}_{3}\right)$, on serum $\mathrm{T} 3, \mathrm{~T} 4$, thyroid stimulating hormone $(\mathrm{TSH})$, parathyroid hormone (PTH) and calcium ( $\mathrm{Ca})$ levels and thyroid tissue. In addition, this research is important as one of the rare studies in which thyroid tissue was subjected to histological examination.

Methods: Thirty-two male Sprague Dawley rats were assigned into groups consisting of eight animals each, based on weight; Group I: Sham control, Group 2: $\mathrm{Li}_{2} \mathrm{CO}_{3}+25 \mathrm{mg} / \mathrm{kg}$, Group 3: $\mathrm{Li}_{2} \mathrm{CO}_{3}+50 \mathrm{mg} / \mathrm{kg}$ and Group 4: $\mathrm{Li}_{2} \mathrm{CO}_{3}+100 \mathrm{mg} / \mathrm{kg}$. $\mathrm{Li}_{2} \mathrm{CO}_{3}$ was administered orally at varying concentrations, at I $\mathrm{mL}$ per day for 30 days. Serum samples were separated from blood obtained by intracardiac intervention. Serum T3, T4, TSH, PTH and Ca levels were measured by using an autoanalyzer and chemiluminescence. Thyroid tissue was examined under light microscopy after routine histopathological procedures.
\end{abstract}

Results: T3, T4, PTH and Ca levels increased in rats treated with high-dose $\mathrm{Li}_{2} \mathrm{CO}_{3}$, whereas TSH levels were very low in all groups. In addition, thyroid tissue exhibited concentration-dependent histological alterations.

Conclusion: $\mathrm{Li}_{2} \mathrm{CO}_{3}$, which was administered subacute high dose in rats, caused of increased T4 and T3 hormones levels, hyperparathyroidism and hypercalcemia in the early period. These results now need to be supported by further experimental and clinical studies.

\section{INTRODUCTION}

Although the mood stabilizing effects of lithium carbonate $\left(\mathrm{Li}_{2} \mathrm{CO}_{3}\right)$ have long been known, over the last 40 years it has become a frequently employed agent in the treatment of bipolar disorders. ${ }^{[1,2]}$ It is also used as an adjunct drug in treatment-refractory depression. ${ }^{[3]}$ Previous research has demonstrated that lithium carbonate exhibits beneficial therapeutic effects by affecting excitatory and inhibitory mechanisms in the brain, although considering the complex pathophysiology of bipolar disorder, the exact effect mechanism is still not fully understood. ${ }^{[4]}$ The desired remission in bipolar disorder, a chronic and severe entity, can be achieved with appropriate therapeutic options. ${ }^{[5]}$ However, difficulties in drug selection and failure to achieve a response to the selected medication may result in the failure of the planned treatment. ${ }^{[6]}$

Bipolar disorder is one of the principal psychological problems, affecting approximately $2.4 \%$ of the world pop- ulation. ${ }^{[7]}$ Lithium occupies an important place among the main drugs used in prophylactic treatment, and is frequently employed in combination with anticonvulsants, antipsychotics, and antidepressants treatment. ${ }^{[8,9]}$ However, increasing blood-drug levels due to long-term lithium use, can result in dysfunction in several organs, especially the kidneys. ${ }^{[10,1]]}$ Other significant problems include thyroid and parathyroid function anomalies. ${ }^{[10,12]}$ Lithium use-related impairment of thyroxin (T4) and triiodothyronine (T3) synthesis and secretion occurs in the form of mild hypofunction, but these may sometimes remain at normal levels. ${ }^{[13]}$ Increases have also rarely been reported. ${ }^{[14]}$

One of the problems encountered with long-term lithium therapy is parathyroid function impairment, and an increase in circulating calcium. ${ }^{[15,16]}$ In previous studies, the hypothesis that kidney dysfunction occurring after chronic lithium use may be related to PTH and circulating calcium level. ${ }^{[17,18]} \mathrm{A}$ previous study also showed that potential 
deleterious conditions can be prevented by assessing PTH and calcium levels before and during lithium therapy. ${ }^{[19]}$

The aim of this research was to investigate the endocrinological effects of experimental subacute lithium application at different concentrations on serum T3, T4, TSH, PTH and calcium levels and thyroid tissue and to reveal the relations between them. Our research is also important as one of the rare biochemical analyses of these hormones and histological examinations of thyroid tissue.

\section{MATERIALS AND METHODS}

\section{Experimental animals}

The research was conducted using cadaver tissue and sera left over from the study titled"An In Vivo and In Vitro Evaluation of the Lithium Comet Assay Used in the Treatment of Bipolar Disorder and Genotoxicity"under ethical committee permission No 2019/39 dated 29.11.2019.

Thirty-two male Sprague Dawley rats weighing $290 \pm 10 \mathrm{~g}$ were employed for the purpose of biochemical and histological investigation. These were treated in line with the principles of the Guideline for the Care and Use of Laboratory Animals issued by the National Research Council and approved by the local ethical committee guideline. Prior to and during the course of the study, the rats were kept in standard plastic cages with straw floors, at a temperature of $22 \pm 2^{\circ} \mathrm{C}$ in $55-65 \%$ humidity and under controlled lighting (a 12/12 hour light/dark cycle). Unrestricted access was permitted to standard rat chow and tap water. All animal experiments and procedures were conducted as required by national regulations concerning the care and use of laboratory animals. The study protocol was approved by the Recep Tayyip Erdogan University Institutional Ethical Committee, Turkey (No. 2018/56 dated 23.II.2018).

\section{Chemicals}

Lithium carbonate $\left(\mathrm{Li}_{2} \mathrm{CO}_{3}\right)$ (Lithuril $300 \mathrm{mg} 100$ capsule) was obtained from Koçak Farma İlaç ve Kimya Sanayi A.Ş. (İstanbul, Turkey). Ketamine hydrochloride (Ketalar, 50 $\mathrm{mg} / \mathrm{kg}$, Pfizer İlaçları Ltd. Şti., İstanbul, Turkey) was used to anesthetize all animals, and xylazine hydrochloride (Rompun, $10 \mathrm{mg} / \mathrm{kg}$, Bayer, Turkey) was administered for sedation. Other chemicals disposed for laboratory analyses were procured from Sigma Chemical Co. and Merck (Germany).

\section{Experiment design}

At the beginning of the study, rats were assigned into groups consisting of eight animals each, based on weight;

I. Sham control

2. $\mathrm{Li}_{2} \mathrm{CO}_{3}+25 \mathrm{mg} / \mathrm{kg}$

3. $\mathrm{Li}_{2} \mathrm{CO}_{3}+50 \mathrm{mg} / \mathrm{kg}$ and

4. $\mathrm{Li}_{2} \mathrm{CO}_{3}+100 \mathrm{mg} / \mathrm{kg}$

\section{$\mathrm{Li}_{2} \mathrm{CO}_{3}$ Application}

All procedures were carried out under sterile conditions. Following assignment into groups, those rats scheduled for drug administration received $\mathrm{Li}_{2} \mathrm{CO}_{3}$ at the concentrations described above in a total $\mathrm{I} \mathrm{mL}$ volume every day for 30 days via the oral route. The sham control group received water in which the drug was dissolved at the same volume. Vital activities were checked every day during administration. At the end of the experiment, rats were sacrificed with the administration of high-dose anesthetic. Blood specimens collected by intracardiac intervention were placed into tubes without anticoagulant and centrifuged at $3000 \mathrm{~g}$ for $10 \mathrm{~min}$ at $+4^{\circ} \mathrm{C}$ and then stored at $-80^{\circ} \mathrm{C}$ until biochemical analysis. Thyroid tissue was placed into 10\% neutral formalin for histopathological examination.

\section{Biochemical analysis}

Biochemical examinations were performed at the Recep Tayyip Erdogan University Training and Research Hospital Medical Biochemistry Department laboratory. Sera were vortexed, and FT3, FT4, TSH, PTH and Ca levels were measured by using the chemiluminescence technique on an Architect i2000 autoanalyzer (Abbott Diagnostics, USA).

\section{Histological analysis}

Rat thyroid tissue specimens were divided into $1.5 \mathrm{~cm}^{3}$ pieces and fixed for $48 \mathrm{~h}$ in $10 \%$ neutral formalin solution (Sigma-Aldrich, Germany). Following the fixation procedure, the thyroid tissue specimens were dehydrated by being passed through increasing ethanol (Merck $\mathrm{GmbH}$, Darmstadt, Germany) series, and then cleared in xylol solution (Merck, Darmstadt, Germany). Next, the thyroid tissues were embedded in paraffin blocks (Merck $\mathrm{GmbH}$, Darmstadt, Germany). Sections 4-5 $\mu \mathrm{m}$ in thickness were than taken from these blocks, stained with Harris hematoxylin (Merck GmbH, Darmstadt, Germany) and Eosin G (Merck, Darmstadt, Germany), examined under a light microscope (Olympus Corp., BX5I, Japan) and photographed using a digital camera (Olympus Co., DP7I, Japan).

\section{Semi-quantitative analysis}

Histopathological findings observed in thyroid tissue sections were scored in line with previous studies involving histopathological analysis after thyroid toxicity, as shown in Table 2. Fifteen non-contiguous and randomly selected areas in each preparate were assessed by two independent histologists blinded to the study groups.

\section{Quantitative analysis}

Follicle surface area in the thyroid tissue sections was scored as shown in Figure I on Olympus DP2 software (Olympus Corp., Tokyo, Japan). Fifteen non-contiguous and randomly selected areas in each preparate were evaluated by two independent histologists blinded to the study groups. 


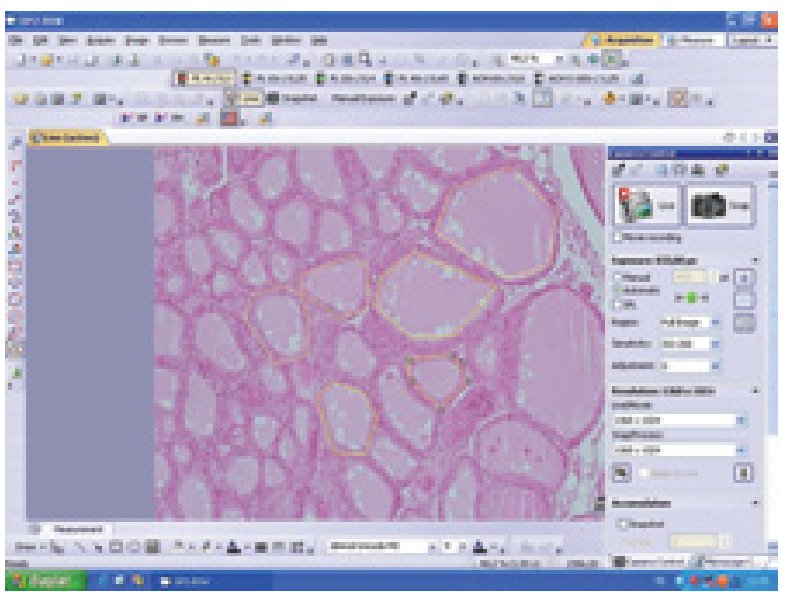

Figure 1. Representative light microscopic image of quantitative analysis of H\&E-stained thyroid tissue sections.

\section{Statistical analysis}

All statistical analyses were performed on SPSS I8.0 (IBM, Armonk, NJ, USA) software. Data obtained from biochemical analyses were subjected to the Shapiro-Wilk test to evaluate normality of distribution and were calculated as mean \pm standard deviation. Intergroup comparisons were performed using One-Way ANOVA followed by the LSD test. Non-parametric data yielded by histopathological analyses were calculated as median, and $25 \%$ and $75 \%$ interquartile ranges. Intergroup differences were analyzed using the non-parametric Kruskall Wallis test followed by the Tamhane T2 test. $P$ values $<0.05$ were regarded as statistically significant.

\section{RESULTS}

\section{Biochemical results}

Hormone levels were measured after 30 days of lithium carbonate administration. T4 levels were lower in the control group compared to the other study groups, although the difference was only statistically significant between the control group and $\mathrm{Li}_{2} \mathrm{CO}_{3}+100 \mathrm{mg} / \mathrm{kg}$ group $(p=0.00 \mathrm{I}$; Table I). On the other hand no statistically significant difference was detected between the control group and the other groups ( $p>0.05$; Table I).

Similarly, T3 levels only differed significantly between the control and $\mathrm{Li}_{2} \mathrm{CO}_{3}+100 \mathrm{mg} / \mathrm{kg}$ group $(p=0.03$; Table I).
While differences were observed with the other groups, these not reach statistical significance ( $>>0.05$; Table I). Another parameter measured together with T4 and T3 hormone levels was TSH. However, this study is that serum TSH levels are below $<0.0 \mathrm{l}$ ulU/mL in all groups. In the high dose lithium treated groups, the low serum TSH levels expected to occur due to the increase in serum thyroid hormon was observed in all groups in the study. However, low detection of TSH levels in the control group suggests that this decrease may have been due to the measurement method rather than the lithium effect.

Differences in PTH levels were determined between the study groups, but these were not statistically significant ( $p>0.05$; Table I).

A further parameter studied in the present research was $\mathrm{Ca}$ levels, and differences were again observed between the control and other groups. The differences between the $\mathrm{Li}_{2} \mathrm{CO}_{3}+100 \mathrm{mg} / \mathrm{kg}$ and the control and other study groups were statistically significant $(p=0.03$; Table I).

\section{Histopathological analysis results}

Normal follicular cells, follicles and normal colloid contents were observed in the control group thyroid tissue sections (THDS median: 0 (0-I); Fig. 2; Table 3). Typical follicles were observed in thyroid tissue sections from Group I (THDS median: 2 (I-2); Fig. 3; Table 3). In contrast, Group

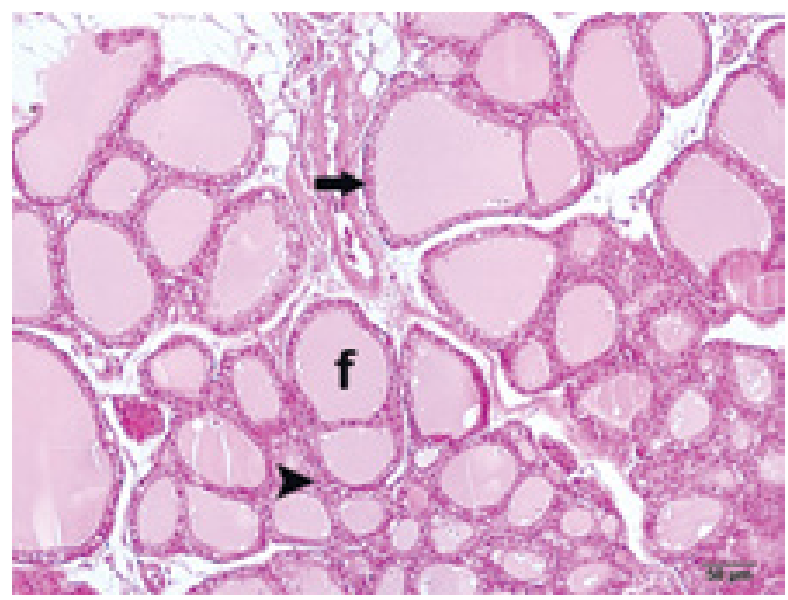

Figure 2. Representative light microscopic image of H\&Estained thyroid tissue sections. (x20): Control group sections exhibiting normal follicular cells (f) THDS median: 0 (0-1)

Table I. Biochemical analysis scores

\section{Parameters measured}

\begin{tabular}{lcccc}
\cline { 2 - 5 } Study groups & FT4 $(\mathbf{n g} / \mathbf{d L})$ & FT3 $(\mathbf{p g} / \mathbf{m L})$ & PTH $(\mathbf{p g} / \mathbf{m L})$ & $\mathbf{C a}(\mathbf{m g} / \mathbf{d L})$ \\
\hline I. Control & $1.02 \pm 0.10$ & $1.18 \pm 0.14$ & $4.80 \pm 1.89$ & $9.38 \pm 0.29$ \\
$2 . \mathrm{Li}_{2} \mathrm{CO}_{3}+25 \mathrm{mg} / \mathrm{kg}$ & $1.09 \pm 0.13$ & $1.50 \pm 0.41$ & $7.92 \pm 3.35$ & $9.87 \pm 0.24$ \\
$3 . \mathrm{Li}_{2} \mathrm{CO}_{3}+50 \mathrm{mg} / \mathrm{kg}$ & $1.09 \pm 0.42$ & $1.42 \pm 0.33$ & $8.33 \pm 7.04$ & $9.71 \pm 0.26$ \\
$4 . \mathrm{Li}_{2} \mathrm{CO}_{3}+100 \mathrm{mg} / \mathrm{kg}$ & $1.25 \pm 0.57^{\mathrm{a}}$ & $1.60 \pm 0.29^{\mathrm{b}}$ & $11.70 \pm 7.06$ & $10.25 \pm 0.48^{\mathrm{a}}$ \\
\hline
\end{tabular}

a: differs statistically significantly from the control group at $p=0.00 \mathrm{I} ;{ }^{\text {b }}$ : differs statistically significantly from the control group at $p=0.03$. 
Table 2. Thyroid histopathological damage scoring (THDS)

\begin{tabular}{cc}
\hline Finding & Score \\
\hline Necrotic follicular cells & \\
0 & less than $<5 \%$ \\
1 & between $6 \%-25 \%$ \\
2 & between $26 \%-50 \%$ \\
3 & More than $51 \%$ \\
Follicles with loss of colloid content & \\
0 & less than $<5 \%$ \\
1 & between $6 \%-25 \%$ \\
2 & between $26 \%-50 \%$ \\
3 & More than $51 \%$ \\
Degenerative follicle (Necrotic follicular & \\
epithelial cells and loss of colloid content & \\
with in the follicular lumens) & \\
0 & less than $<5 \%$ \\
I & $6 \%-25 \%$ \\
2 & $26 \%-50 \%$ \\
3 & More than $51 \%$
\end{tabular}

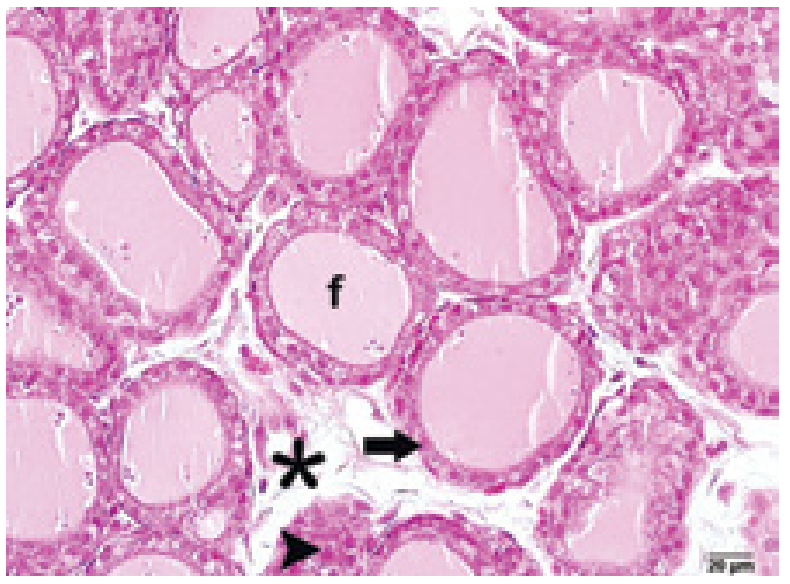

Figure 3. Representative light microscopic image of H\&Estained thyroid tissue sections. (x20): Sections from Group 1 exhibiting typical follicular cells and colloid content(f) THDS median: 2 (1-2).

2 thyroid tissue sections exhibited degenerative follicles with necrotic cells and loss of colloid content (THDS median: 3 (2-3); Fig. 4; Table 3). Degenerative follicles consisting of necrotic cells and with loss of colloid content were
Table 4. Thyroid follicle surface area measurements (mean \pm standard deviation)

\begin{tabular}{lc}
\hline Group & Follicle area $\left(\mu \mathrm{m}^{2}\right)$ \\
\hline Control & $31.312 .99 \pm 12.541 .40$ \\
Group I & $328.668 .17 \pm 43.470 .64^{\mathrm{b}}$ \\
Group 2 & $307.564 .97 \pm 46.055 .91^{\mathrm{c}}$ \\
Group 3 & $141.618 .74 \pm 61.044 .28^{\mathrm{a}}$ \\
\hline
\end{tabular}

${ }^{a} p=0.001$; versus the control group; ${ }^{b} p=0.001$; versus Group 3; ${ }^{c} p=0.001$; versus Group 3; One-Way ANOVA-Bonferroni test.

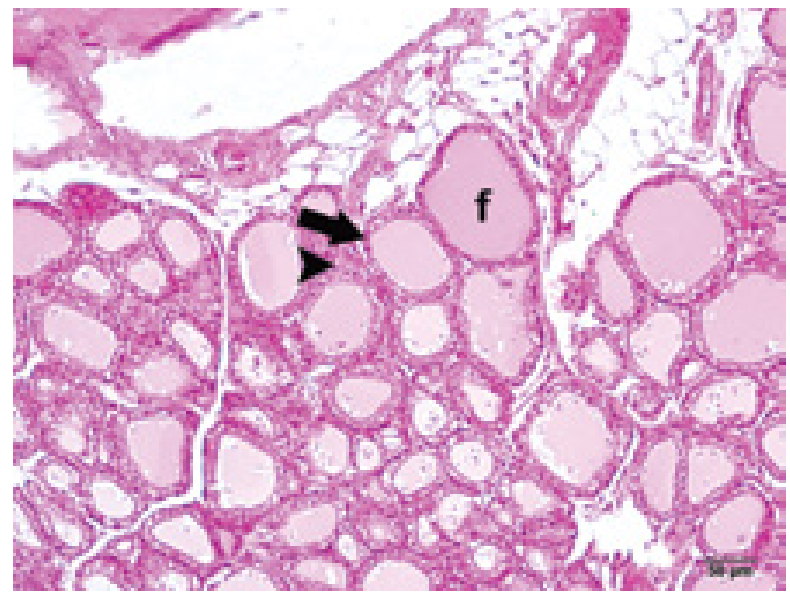

Figure 4. Representative light microscopic image of H\&Estained thyroid tissue sections. (x20): Group 2 sections exhibiting typical follicular cells (f) THDS median: $3(2-3)$.

observed in thyroid tissue sections from Group 3 (THDS median: 5.5 (5-6.5); Fig. 5; Table 3).

\section{Semi-quantitative analysis results}

We observed no difference in terms of necrotic follicular cells and follicles with cause loss of colloid between the control group and groups I and 2 (Fig. 2-4; Table 3). In contrast, degenerative follicles were found to have increased in Group 3 compared to the control group (Fig. 5; Table 3). We also determined an increase in necrotic follicular cells, follicles with loss of colloid content (degenerative follicles) in Group 3 section compared to the control group (Fig. 5; Table 3; $p=0.002 ; p=0.000 ; p=0.00$, respectively). In this study, pale colloid and resorption vacuoles were seen in the follicle lumens that increased depending on the dose.

Table 3. THDS results (median (25\%-75\% interquartile range))

\begin{tabular}{lcccc}
\hline Group & Necrotic follicular cells & Follicles with loss of colloid content & Degenerative follicles & THDS \\
\hline Control group & $0(0-I)$ & $0(0-0)$ & $0(0-0)$ & $0(0-I)$ \\
Group I & $1(0.5-I)$ & $0.5(0-I)$ & $0(0-I)$ & $2(I-2)$ \\
Group 2 & $I(I-I)$ & $I(0-I)$ & $I(0.5-I)^{\mathrm{c}}$ & $3(2-3)^{\mathrm{d}}$ \\
Group 3 & $2(2-2.5)^{\mathrm{a}}$ & $2(2-2)^{\mathrm{b}}$ & $\mathrm{I}(\mathrm{I}-2)^{\mathrm{d}}$ & $5.5(5-6.5)^{\mathrm{b}}$ \\
\hline
\end{tabular}

${ }^{a} p=0.002$ versus the control group; ${ }^{b} p=0.001$ versus the control group; ${ }^{c} p=0.05$ versus the control group; ${ }^{d} p=0.001$ versus the control group; Kruskal Wallis/ Tamhane $\mathrm{T} 2$ test. 


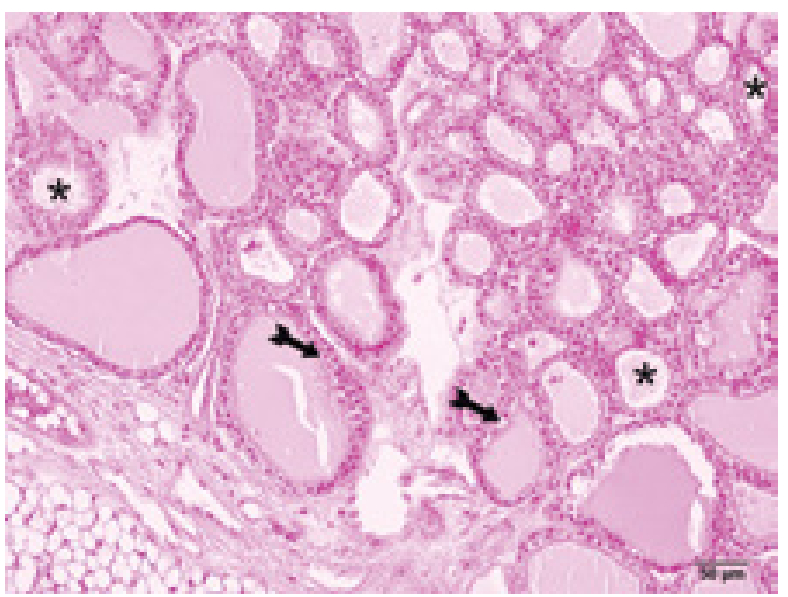

Figure 5. Representative light microscopic imageof H\&Estained thyroid tissue sections. (x20): Sections from Group 3 showing Necrotic follicular epithelial cells with cytoplasmic vacuoles, follicles with pale or absence of colloid. (TDS median: $5.5(5-6.5))$.

\section{Quantitative analysis results}

No difference was determined between the control group and groups $I$ and 2 in terms of follicle surface area (Fig. 2-4; Table 4). In contrast, follicle surface area decreased in Group 3 compared to the control group (Fig. 2-5; Table 4: $\mathrm{p}=0.00 \mathrm{I})$. Similarly, a significantly lower follicle surface area was observed in Group 3 than in groups I and 2 (Fig. 3-5; Table 4; $p=0.000$ and $p=0.001$, respectively).

\section{DISCUSSION}

This experimental study was performed in order to reveal the effects on the thyroid of different doses and concentrations of lithium carbonate, with its significant role in the treatment of bipolar disorder, one of the mood disorders. Monitoring blood-drug levels of lithium, with its narrow therapeutic index, during treatment is useful in terms of the taking of precautions against potential side-effects. In addition, this research will also contribute to determine the most appropriate rat dosage in experimental studies using lithium carbonate. Our experimental research showed the adverse effects of high-dose lithium administered at various doses.

In lithium toxicity, in addition to absence of clinical signs and asymptomatic conditions, nausea, vomiting, tremor, hyperreflexia, agitation, weakness and ataxia are regarded as indicating mild toxicity, drowsiness, stiffness, hypertonia and hypotension as moderate toxicity, and myoclonus, cardiovascular collapse, seizure and coma as potentially severe intoxication. ${ }^{[20]}$ It has also been shown to cause nephrogenic diabetes insipidus, usually hypothyroidism, uncommonly hyperthyroidism. ${ }^{[21-23]}$

Previous research has also reported hypothyroidism emerging with decreased thyroid hormone release after long-term lithium use as a common and important clinical finding, and that it may also rarely lead to hyperthyroidism.
[24-29] Similarly in the present research, and consistent with previous studies, we observed that early period serum T4 and T3 levels increased in a dose-dependent manner. However, late stage of lithium will cause hypothyroidism. [28] The presence of higher concentrations in thyroid tissue than in plasma following lithium intake explains the cause of the changes caused in thyroid functions. ${ }^{[30]}$ Although the mechanism involved in hyperthyroidism caused by lithium is not yet fully understood, the concentrations may have increased with a rebound effect in association with drug discontinuation, while studies have also reported serum thyroid elevation under the effects of follicle damage, autoantibody synthesis and other underlying disease. ${ }^{[25,29,31,32]}$ In contrast, Kuman et al. ${ }^{[33]}$ reported no association between lithium therapy and hyperthyroidism, although Shine et al. suggested that hyperthyroidism may appear after treatment lasting several years. ${ }^{[34]}$ Additionally, the possibility of hyperthyroidism after lithium administration has also been shown in several case reports. ${ }^{[1,35,36]}$ In this study, however, there were no follicular damage and destruction, pale colloid and resorption vacuoles were seen in the follicle lumens that increased depending on the dose. These morphological findings are changes that can be observed in thyroid follicles in case of hyperfunction. Intake of lithium in high doses may cause an increase in follicular epithelial cell functions and this type of morphological changes in subacute period.

In our study, necrotic cells and follicles with loss of colloid content were detected in the early period after high dose lithium application, and an increase in serum thyroid hormone levels were detected in this process. However, it can be predicted that in the late period, hypothyroidism will occur with a decrease in serum level against this condition.

Another endocrinological problem seen with lithium therapy is parathyroid abnormalities. ${ }^{[16,37]}$ Previous research has revealed that the incidence of hyperparathyroidism increases with lithium therapy. ${ }^{[38]}$ Similarly, in the present experimental research we observed that the increase in PTH levels may be associated with the lithium dosage applied. These findings are consistent with previous research. In addition, calcium level elevation with high-dose administration was consistent with PTH, and this change may have altered the effect of lithium and calcium-sensing receptors. Livingstone $\mathrm{C}$ et al. ${ }^{[22]}$ also revealed that $\mathrm{PTH}$ levels change through a similar mechanism. ${ }^{[39]}$

Kidney related side effects occur in approximately $20 \%$ of patients after long-term treatment with lithium. ${ }^{[40]}$ Hestbech et al. ${ }^{[41]}$ in a study conducted in patients with lithium intoxication, they revealed the development of chronic tubulointerstitial nephritis. Similarly, Markowitz et al. ${ }^{[42]}$ showed that kidney was affected by combined glomerular and tubulointerstitial damage following lithium toxicity. In addition, in experimental studies, it was stated that tubular lesion and dilatation occurred after lithium exposure. However, this mechanism is unclear. ${ }^{[43]}$ The risk of chronic kidney damage occurring in the later stages of chronic 
lithium administration may contribute to the formation of hyperparathyroidism. ${ }^{[39]}$ It has been reported that the cause of hypercalcemia that occurs may also be the result of hyperparathyroidism. ${ }^{[44]}$ In this study, where subacute lithium was administration, we observed increased PTH and $\mathrm{Ca}$ levels similar to previous studies.

The limitation of this study is that serum TSH levels are below $<0.01 \mathrm{ulU} / \mathrm{mL}$ in all groups. In the high dose lithium treated groups, the low serum TSH levels expected to occur due to the increase in serum thyroid hormon was observed in all groups in the study. This may be due to measurement methods. The amount of serum we obtained was not large enough to enable us to measure again. However, this research was performed as a pilot study to shed light on future research, and the findings now need to be confirmed by further studies considering intracellular pathways.

In conclusion, this study was an experimental investigation of the potential endocrinological outcomes of lithium therapy at different doses. In addition, our results suggest that lithium carbonate which was administered subacute high dose in rats, caused increased T4 and T3 hormones levels, hypercalcemia and hyperparathyroidism in the early period. However, hormone levels that increase temporarily in the short term following the application of lithium carbonate will decrease in the long term and may cause hypothyroidism. These data now need to be supported by further experimental and clinical research.

\section{Acknowledgments}

The author is profoundly grateful to Associate Professor Dr. Levent Tumkaya and Dr. Tolga Mercantepe of the Recep Tayyip Erdogan University Faculty of Medicine Histology and Embryology Department teaching staff for histological evaluations of thyroid tissues, and to Prof. Dr. Huseyin Avni Uydu of the Medical Biochemistry Department and again to Dr. Tolga Mercantepe for their advice concerning the statistical analyses.

Ethics Committee Approval

The study protocol was approved by the Recep Tayyip Erdogan University Institutional Ethical Committee, Turkey (No. 2019/39 dated 29.11.2019).

Peer-review

Internally peer-reviewed.

Conflict of Interest

None declared.

\section{REFERENCES}

1. Shorter E. The history of lithium therapy. Bipolar Disord 2009;11(Suppl 2):4-9. [CrossRef]

2. Malhi GS, Tanious M, Das P, Coulston CM, Berk M. Potential mechanisms of action of lithium in bipolar disorder. Current understanding. CNS Drugs 2013;27:135-53. [CrossRef]

3. Buspavanich P, Behr J, Stamm T, Schlattmann P, Bschor T, Richter C, et al. Treatment response of lithium augmentation in geriatric compared to non-geriatric patients with treatment-resistant depression. J Affect Disord 2019;251:136-40. [CrossRef]
4. Bowden CL. Bipolar pathophysiology and development of improved treatments. Brain Res 2008;1235:92-7. [CrossRef]

5. Fabbri C, Serretti A. Genetics of long-term treatment outcome in bipolar disorder. Prog Neuropsychopharmacol Biol Psychiatry 2016;65:17-24. [CrossRef]

6. Hidalgo-Mazzei D, Berk M, Cipriani A, Cleare AJ, Florio AD, Dietch $\mathrm{D}$, et al. Treatment-resistant and multi-therapy-resistant criteria for bipolar depression: consensus definition. Br J Psychiatry 2019;214:27-35. [CrossRef]

7. Chandrasekaran V, Brennan-Olsen SL, Stuart AL, Pasco JA, Berk $\mathrm{M}$, Hodge JM, et al. Association between bipolar spectrum disorder and bone health: a meta-analysis and systematic review protocol. BMJ Open 2017;7:e013981. [CrossRef]

8. Yatham LN, Kennedy SH, Parikh SV, Schaffer A, Bond DJ, Frey BN, et al. Canadian Network for Mood and Anxiety Treatments (CANMAT) and International Society for Bipolar Disorders (ISBD) 2018 guidelines for the management of patients with bipolar disorder. Bipolar Disord 2018;20:97-170. [CrossRef]

9. Tohen M, Zarate CA Jr, Hennen J, Khalsa HM, Strakowski SM, Gebre-Medhin P, et al. The McLean-Harvard First-Episode Mania Study: prediction of recovery and first recurrence. Am J Psychiatry 2003;160:2099-107. [CrossRef]

10. Gitlin M. Lithium side effects and toxicity: prevalence and management strategies. Int J Bipolar Disord 2016;4:27. [CrossRef]

11. Bocchetta A, Loviselli A. Lithium treatment and thyroid abnormalities. Clin Pract Epidemiol Ment Health 2006;2:23. [CrossRef]

12. Webb AL, Solomon DA, Ryan CE. Lithium levels and toxicity among hospitalized patients. Psychiatr Serv 2001;52:229-31. [CrossRef]

13. Lazarus JH. The effects of lithium therapy on thyroid and thyrotropin-releasing hormone. Thyroid 1998;8:909-13. [CrossRef]

14. Barclay ML, Brownlie BE, Turner JG, Wells JE. Lithium associated thyrotoxicosis: a report of 14 cases, with statistical analysis of incidence. Clin Endocrinol (Oxf) 1994;40:759-64. [CrossRef]

15. Nair CG, Menon R, Jacob P, Babu M. Lithium-induced parathyroid dysfunction: A new case. Indian J Endocrinol Metab 2013;17:930-2.

16. Szalat A, Mazeh H, Freund HR. Lithium-associated hyperparathyroidism: report of four cases and review of the literature. Eur J Endocrinol 2009;160:317-23. [CrossRef]

17. Bendz H, Sjödin I, Toss G, Berglund K. Hyperparathyroidism and long-term lithium therapy--a cross-sectional study and the effect of lithium withdrawal. J Intern Med 1996;240:357-65. [CrossRef]

18. Bhuvaneswar CG, Baldessarini RJ, Harsh VL, Alpert JE. Adverse endocrine and metabolic effects of psychotropic drugs: selective clinical review. CNS Drugs 2009;23:1003-21. [CrossRef]

19. Kuman Tunçel Ö, Akdeniz F, Özbek SS, Kavukçu G, Ünal Kocabaş G. The Effects of Lithium on Calcium and Parathormone Levels: A Cross-sectional Study with Healthy Controls. Turk Psikiyatri Derg 2019;30:163-71. [CrossRef]

20. Delva NJ, Hawken ER. Preventing lithium intoxication. Guide for physicians. Can Fam Physician 2001;47:1595-600.

21. Grünfeld JP, Rossier BC. Lithium nephrotoxicity revisited. Nat Rev Nephrol 2009;5:270-6. [CrossRef]

22. Livingstone $\mathrm{C}$, Rampes $\mathrm{H}$. Lithium: a review of its metabolic adverse effects. J Psychopharmacol 2006;20:347-55. [CrossRef]

23. Lazarus JH. Lithium and thyroid. Best Pract Res Clin Endocrinol Metab 2009;23:723-33. [CrossRef]

24. Spaulding SW, Burrow GN, Bermudez F, Himmelhoch JM. The inhibitory effect of lithium on thyroid hormone release in both euthyroid and thyrotoxic patients. J Clin Endocrinol Metab 1972;35:90511. [CrossRef]

25. Siyam FF, Deshmukh S, Garcia-Touza M. Lithium-associated hyperthyroidism. Hosp Pract (1995) 2013;41:101-4. [CrossRef] 
26. Kibirige D, Luzinda K, Ssekitoleko R. Spectrum of lithium induced thyroid abnormalities: a current perspective. Thyroid Res 2013;6:3.

27. Fairbrother F, Petzl N, Scott JG, Kisely S. Lithium can cause hyperthyroidism as well as hypothyroidism: A systematic review of an under-recognised association. Aust N Z J Psychiatry 2019;53:384-402.

28. Talwar N, Mohan S, Ravi B, Andley M, Kumar A. Lithium-induced enlargement of a lingual thyroid. Singapore Med J 2008;49:254-5.

29. Mizukami Y, Michigishi T, Nonomura A, Nakamura S, Noguchi M, Takazakura E. Histological features of the thyroid gland in a patient with lithium induced thyrotoxicosis. J Clin Pathol 1995;48:582-4.

30. Lazarus JH, McGregor AM, Ludgate M, Darke C, Creagh FM, Kingswood CJ. Effect of lithium carbonate therapy on thyroid immune status in manic depressive patients: a prospective study. J Affect Disord 1986;11:155-60. [CrossRef]

31. Carmaciu CD, Anderson CS, Lawton CA. Thyrotoxicosis after complete or partial lithium withdrawal in two patients with bipolar affective disorder. Bipolar Disord 2003;5:381-4. [CrossRef]

32. Thompson CJ, Baylis PH. Asymptomatic Graves' disease during lithium therapy. Postgrad Med J 1986;62:295-6. [CrossRef]

33. Kuman Tunçel Ö, Akdeniz F, Özbek SS, Kavukçu G, Ünal Kocabaş G. Thyroid Function and Ultrasonography Abnormalities in Lithium-Treated Bipolar Patients: A Cross-sectional Study with Healthy Controls. Noro Psikiyatr Ars 2017;54:108-15. [CrossRef]

34. Shine B, McKnight RF, Leaver L, Geddes JR. Long-term effects of lithium on renal, thyroid, and parathyroid function: a retrospective analysis of laboratory data. Lancet 2015;386:461-8. [CrossRef]

35. Bandyopadhyay D, Nielsen C. Lithium-induced hyperthyroidism, thyrotoxicosis and mania: a case report. QJM 2012;105:83-5. [CrossRef]
36. de Sousa Gurgel W, Dutra PE, Higa RA, da Costa CB, de Matos e Souza FG. Hyperthyroid rage: when bipolar disorder hides the real disorder. Clin Neuropharmacol 2015;38:38-9. [CrossRef]

37. Skandarajah AR, Palazzo FF, Henry JF. Lithium-associated hyperparathyroidism: surgical strategies in the era of minimally invasive parathyroidectomy. World J Surg 2011;35:2432-9. [CrossRef]

38. Ibrahim Y, Mohamed SE, Deniwar A, Al-Qurayshi ZH, Kandil E. Lithium-Associated Hyperparathyroidism: A Pooled Analysis. ORL J Otorhinolaryngol Relat Spec 2015;77:273-80. [CrossRef]

39. Hanna RM, Hasnain H, Sangalang MD, Han J, Arasu A, Arman F, et al. Three Patients with Lithium-Associated Hyperparathyroidism: Literature Review Regarding Medical and Surgical Management. Case Rep Nephrol Dial 2019;9:108-18. [CrossRef]

40. Boton R, Gaviria M, Batlle DC. Prevalence, pathogenesis, and treatment of renal dysfunction associated with chronic lithium therapy. Am J Kidney Dis 1987;10:329-45. [CrossRef]

41. Hestbech J, Hansen HE, Amdisen A, Olsen S. Chronic renal lesions following long-term treatment with lithium. Kidney Int 1977;12:205-13. [CrossRef]

42. Markowitz GS, Radhakrishnan J, Kambham N, Valeri AM, Hines WH, D'Agati VD. Lithium nephrotoxicity: a progressive combined glomerular and tubulointerstitial nephropathy. J Am Soc Nephrol 2000;11:1439-48.

43. Walker RG, Escott M, Birchall I, Dowling JP, Kincaid-Smith P. Chronic progressive renal lesions induced by lithium. Kidney Int 1986;29:875-81. [CrossRef]

44. Gupta N, Gibson M, Wallace EC. Lithium-Induced Chronic Kidney Disease in a Pediatric Patient. Case Rep Pediatr 2019;2019:5406482.

\section{Lityum Karbonatın Sıçan Tiroid Hormonları, Paratormon, Kalsiyum Seviyesi ve Tiroid Dokusu Üzerine Doza Bağımlı Etkileri}

Amaç: $\mathrm{Bu}$ araştırmanın amacı, subakut lityum karbonat $\left(\mathrm{Li}_{2} \mathrm{CO}_{3}\right)$ kullanımının serum $\mathrm{T} 3, \mathrm{~T} 4$, tiroid uyarıcı hormon (TSH), paratiroid hormon $(\mathrm{PTH})$ ve kalsiyum düzeyleri ve tiroid dokusu üzerindeki etkilerini araştırmaktır. Ayrıca, bu araştırma tiroid dokusunun histolojik incelemeye tabi tutulduğu nadir çalışmalardan biri olarak önemlidir.

Gereç ve Yöntem: Otuz iki erkek Sprague Dawley sıçanı ağırlık bazında her biri sekiz hayvandan oluşan dört gruba ayrıldı; Grup I: Sham kontrolü, Grup 2: $\mathrm{Li}_{2} \mathrm{CO}_{3}+25 \mathrm{mg} / \mathrm{kg}$, Grup 3: $\mathrm{Li}_{2} \mathrm{CO}_{3}+50 \mathrm{mg} / \mathrm{kg}$ ve Grup 4: $\mathrm{Li}_{2} \mathrm{CO}_{3}+100 \mathrm{mg} / \mathrm{kg}$. $\mathrm{Li}_{2} \mathrm{CO}_{3}, 30$ gün boyunca günde $1 \mathrm{ml}$ olarak değişen konsantrasyonlarda oral yoldan uygulandı. Serum örnekleri intrakardiyak müdahale ile elde edilen kandan ayrıldı. Serum T3, T4, TSH, PTH ve Ca seviyeleri bir otoanalizör ve kemilüminesans kullanılarak ölçüldü. Tiroid dokusu rutin histopatolojik işlemlerden sonra ışık mikroskobu altında incelendi.

Bulgular: Yüksek doz $\mathrm{Li}_{2} \mathrm{CO}_{3}$ ile tedavi edilen sıçanlarda T3, T4, PTH ve Ca seviyeleri yükselirken, TSH düzeyleri tüm gruplarda çok düşüktü. Ek olarak, tiroid dokusu konsantrasyona bağlı histolojik değişiklikler sergiledi.

Sonuç: Sıçanlarda subakut yüksek doz uygulanan $\mathrm{Li}_{2} \mathrm{CO}_{3}$ erken dönemde $\mathrm{T} 4$ ve $\mathrm{T} 3$ hormon düzeylerinde artış, hiperparatiroidizm ve hiperkalsemiye neden olmuştur. Bu sonuçların artık daha ileri deneysel ve klinik çalışmalarla desteklenmesi gerekmektedir.

Anahtar Sözcükler: Ca seviyeleri; lityum karbonat; parathormon; sıçan; tiroid hormonları. 